\title{
HEALTH WORKERS' USE OF ELECTRONIC INFORMATION CONCERNING CHILDREN WITH SPECIFIC COMMUNICATION NEEDS
}

\author{
AM Wium \\ M. Log. (UP) \\ Kommunika (C.E.I.C.D), Department of Communication Pathology, University of Pretoria \\ Corresponding author: awium@postino.up.ac.za

\section{E Naudé} \\ M. Log. (UP) \\ Head: Kommunika (C.E.I.C.D), Department of Communication Pathology, University of Pretoria
}

Key Words: electronic information; children with communication disorders; health workers' information needs

\begin{abstract}
Information regarding young children who experience barriers to the development of listening, language and learning is limited in the South African context. Health workers, in particular those involved in intervention with these children, such as medical practitioners, speech-language therapists and audiologists as well as occupational therapists, are in a position to disseminate information to parents and other interested persons, including educators and caregivers. These health workers also have access to and are active users of computers and the Internet. They may therefore benefit from receiving relevant and up-to-date electronic information. The study aimed to assess how these groups of health workers use computers and the Internet, as well as to determine their needs for specific electronic information. The results of this study were applied in developing a website containing relevant information.
\end{abstract}

\section{OPSOMMING}

In die Suid-Afrikaanse konteks is daar beperkte inligting oor jong kinders vir wie daar struikelblokke is in die verwerwing van luister-, taal- en leervaardighede. Gesondheidswerkers wat spesifiek betrokke is by die intervensie van bogenoemde kinders, soos mediese praktisyns, spraak-taalterapeute en oudioloë asook arbeidsterapeute, bevind hulself in 'n posisie waar hulle inligting aan ouers asook ander belanghebbendes, byvoorbeeld onderwysers en versorgers, kan oordra. Hierdie gesondheidswerkers het ook toegang tot en is aktiewe gebruikers van rekenaars en die Internet. Hulle kan dus daarby baat om relevante en resente inligting elektronies te ontvang. Die doel van hierdie studie was om hierdie groepe gesondheidswerkers se rekenaar- en Internetgebruik te bepaal asook om hulle inligtingsbehoeftes vas te stel. Die inligting wat hieruit verkry is, is gebruik om ' $n$ webwerf met relevante inligting te ontwikkel. 


\section{INTRODUCTION AND BACKGROUND}

It is important to supply information to health workers who are specifically involved with the intervention of young children experiencing barriers to the development of listening, language and learning. These specific health workers (medical practitioners, speech-language therapists and audiologists, and occupational therapists) find themselves in the position where they have to decide about intervention, as they have to assist families in identifying available service providers and advocacy organisations within their communities (Smith \& Prelock, 2002:124). New developments during the past two decades emphasise the importance of early intervention where barriers to the development of listening, language and learning are identified and addressed at a very young age. It can be anticipated that the lack of early intervention might have a lasting effect on education and success in school and might also have a secondary detrimental effect on social and economic life (Driscoll \& Nagel, 2002:481). The importance of obtaining an early diagnosis of specific disabilities and the provision of suitable information for referral and therapy (early intervention) cannot be overemphasised.

Recent studies (Hendrickson, Baldwin \& Allred, 2003:1) reported that parents blamed professionals for being unable to identify early developmental delays in children and for insufficient referral information to implement timely interventions. Reportedly, dissatisfaction existed among parents about the availability of and access to community resources, transition services, and availability of written information for families of children with specific special needs (Davidson, Silva, Sofis, Ganz \& Palfrey, 2002: 223). Parents were dissatisfied with the information they received from physicians, and sought additional information to learn more about the condition, to control the intervention of the professionals, and to be able to explain the condition to others (Starke \& Moller, 2002:247). Parents who received little or no information experienced feelings of insecurity and helplessness five times more often than those who were satisfied with the information and advice received (Taanila, Syrjala, Kokkonen \& Jarvelin, 1998: 509). These studies were conducted in first world countries with an extensive array of available resources. In South Africa, with limited resources and meagre services, the position might be even less favourable. Effective health care depends on accurate and timely information and intervention (Starke \& Moller, 2002:245), and networking can be a valuable support system for parents of children with specific special needs. The knowledge gained from accessing appropriate information might enable people to make better informed decisions and bring about more constructive changes to the benefit of their children or charges. Appropriate information sharing is therefore invaluable for successful intervention. The benefits include the following:

- Access to applicable and user-friendly information can assist parents to become empowered, competent and self-sufficient (Mitchell \& Sloper, 2002:80).

- A United Kingdom study (Pain, 1999:310) found that the provision of information enhanced the emotional adjustment of parents to these children's disabilities as it enabled parents to access services and benefits, and improved the management of their children's behaviour.

- When parents received adequate information regarding their children, their interventions were more effective. The children benefited as they improved in performance and skill because their parents were knowledgeable about age appropriate behaviour as well as behaviour management. Parents could cope with their reactions to having children with disabilities by obtaining information and gaining knowledge about their children's diagnosis (Starke \& Moller, 2002:247).

- Parents of physically or intellectually disabled children coped better when given sufficient information. Effective collaborative team work between the physicians, nurse practitioners and other health care professionals, however, remained important (Magnusson, Hanson, Brito, Berthold, Chambers \& Daly, 2002:80).

Health workers might find themselves in positions where they need to give advice about issues relevant to, but beyond, their own professional limits (Alderson \& Goodey, 1998: 48). Providing these professionals with suitable information is vital, as they disseminate the information to their clients. Worldwide (Davidson et al. 2002:219; Mitchell \& Sloper, 2002: 74; Starke \& 
Moller, 2002: 245 ) there appears to be a general lack of knowledge in communities (including the medical community) regarding the availability of services for children with developmental delays. There seems to be a universal need for an accessible information source, with lists of service providers, and other resources to provide services to families of children with specific special needs. In order to make the proper referrals, it is important that professionals should know about the available services, where they are provided and by whom. Some useful databases such as http:// www.update-software.com/Cochrane and http:// www.child.nih.gov exist, but are specifically applicable to the United Kingdom and to the United States of America and might not provide information pertaining to the South African context. It might, however, be useful to establish links to such international websites in order to enhance the knowledge of South African caregivers.

Speech-language therapists who are based in schools often assume the responsibility of care coordinators (case managers). Information on how to apply the role of care coordinator working with school age children is very limited, especially in South Africa (Smith \& Prelock, 2002:124; Fouché \& Naudé, 1999:12). Some of the potential responsibilities assigned to care coordinators are similar to those described in health care, early intervention and social work, and entail a leadership role in developing the Individualised Educational Plan/Individualised Family Service Plan. They have to assist families in identifying available service providers and advocacy organisations within their communities (Smith \& Prelock, 2002:124). Consequently, they need to have access to relevant information.

Generally, when information is required on any topic, it is obtained from sources such as printed matter (reference books, journals, magazines, and newsletters), courses, formal education, talking to other professionals and experts, the electronic media (radio and television) and also the Internet (Driscoll \& Nagel, 2002:521). Information technology is viewed as the only realistic vehicle to provide the required information because of the dispersed nature of mental health services, as well as services for children with specific special needs (Blackburn, 2001:210). The widespread geographical areas for service delivery in South
Africa could increase reliance on information technology for information access and information sharing. It has become easier to obtain information from the Internet, where information is distributed through standardised protocols. It is an international but complex communication medium that has changed the speed, quality, processing, retrieval and transmission of information. However, not all information provided on the Internet should be accepted as accurate and/or appropriate. It should be used in a discerning manner and with caution as a source of information. It therefore places a responsibility on service providers to supply accurate and relevant information on the Internet. Although the main use of the Internet is for communication (e-mail), and information, it is also the medium for the distribution of digital publications. The advantages of the Internet include that it is quick, low on distortion, available at all times and relatively inexpensive once the hardware and software have been installed. The disadvantage is that the original costs of purchasing a computer and Internet access are high; people also need to know how to operate a computer and access the Internet, which requires some expertise. In South Africa, the Internet is growing by 15000 subscribers per month and the number of people accessing the Internet at work is five to six times higher than indicated by these figures (Naudé, 1997:43). The Internet is regarded as a valuable source of information, is fairly accessible and is time effective. In this digital age, people require information that can add time value and content value to their lives (Aldrich, 1999:30). It is furthermore evident that computers and the Internet will play a vital role in health care issues in the $21^{\text {st }}$ century where telecommunication technology will be a significant tool in educating and distributing health-related information to people with disabilities. This emerging field of interactive health care (Science Panel on Interactive Communication and Health, 1999) enables health workers to provide guidance and support on health-related issues, and to provide a wider range of choices (Pickett Hauber et al. 2002:142).

Clinicians reported (Naudé, 2003) that when children are diagnosed with specific conditions or disabilities (such as experiencing barriers to the development of listening, language and learning), the majority of parents request information in order to deal with their situations. It is therefore essential that specific information be supplied and made electronically accessible 
to parents, health workers and educators. The provision of this type of information should enable health workers to provide improved services. The development of a website with specific information could be valuable in service delivery. In order to provide such a website, it was necessary to establish health workers' information needs pertaining to this field and to assess their computer and Internet use.

\section{RESEARCH}

\section{Aim of the study}

The purpose of this study was to determine the computer and Internet use of health workers, and to determine their electronic information needs in order to supply relevant information concerning young children with specific special needs on a proposed website. A new generation of professionals who come of age in the digital era will become more effective on the Internet in their quest for knowledge and search for information in an effort to solve their problems (Tapscott, 1999:ix). Input from both parents and professionals (Kommunika Seminar, 2003) indicated a strong need for a website with information on young children who experience barriers to the development of listening, language and language-related learning in South Africa. The possibility of such a website with information on the target group of children, the first of its kind in South-Africa, should be investigated.

\section{Research design}

This study used a descriptive cross sectional survey design (Leedy \& Ormrod, 2001:194). The data collection tool was a mailed and self-administered questionnaire. The data collection took place during September, October and November 2002.

\section{Respondents}

This group comprised three sub-groups who were selected on grounds of their particular involvement in the intervention of this specific group of children. The following numbers were selected for the sample:

Medical Practitioners (93): Specialist practitioners such as ear nose and throat specialists, paediatricians, neurologists and psychiatrists were usually involved with children experiencing barriers to listening, language and learning. They were selected on grounds of convenience and availability as they were at a specific place and time and data had to be collected in the easiest way possible with the least cost and effort (Maisel \& Percell, 1996:4). These medical practitioners (ear nose and throat specialists, paediatricians, neurologists and psychiatrist), were listed in the Pretoria telephone directory. It was anticipated that these above-mentioned medical practitioners might have found the database useful for referral purposes, for personal use, or for telling their patients about such a resource.

\section{Speech-Language Therapists and Audiologists}

$(n=100)$ : These professionals are often requested to provide information to parents. The database of service providers and special schools would therefore be very helpful to this group. The list of registered speechlanguage therapists and audiologists was obtained from the Health Professionals Council of South Africa and the sample $(n=100)$ was systematically selected with a random starting point.

Occupational Therapists $(n=100)$ : Occupational therapists were included in the study because they also work with these children. The list of occupational therapists working in paediatric practice was obtained from the Occupational Therapy Association of South Africa. Once again, a sample of 100 was systematically selected with a random starting point.

\section{Material and apparatus}

The information required for this study was obtained by means of a questionnaire consisting of 13 questions. The first two questions obtained general identifying information about the professionals targeted for the research project. The third question determined their mode of seeking information and the following three questions focused on their use of the Internet. Two questions ascertained respondents' needs for a newsletter. Two checklists requested information on website functions and information desired from the proposed website. Finally, respondents were asked for comments or recommendations about this proposed website and also to indicate whether they wished to be listed in the database as service providers. Content validity was enhanced by having the questionnaire reviewed by four experts to ensure that it included necessary, and omitted unnecessary aspects. The questionnaire items were pertinent to the study's objectives. The content validity was also con- 
firmed by testing the questionnaires amongst two respondents from each of the three groups (these persons were excluded from participating in the actual study). They commented on the questionnaire, requested clarification of one specific term, and suggested that an additional option to be added to the list of work environments

\section{Data analysis}

The quantitative nature of the data determined that data be entered as numerical values. In this case, a coding system was formulated and questionnaires were designed as pre-coded forms. All participants were requested to complete the form after reading the cover letter. Each questionnaire was assigned a number (identification code) in the right top corner upon receipt (Mangione, 1995: 98). This study made use of nominal (categorical) and ordinal data derived from rating scales. The data was analysed by constructing frequency tables which reflected the objectives of the survey, and were based upon derived data, or upon the original data. They provided a complete picture of the distribution of data for the variable, and were used in interpreting the results of this study. These results formed the basis for the design of the website and identified critical areas to be included, as well as an indication of detail required.

\section{RESULTS}

The response rate to the questionnaire was $29 \%$ $(n=86)$. The specific sub-groups responded as follows: speech-language therapists and audiologists $(n=31)$; medical practitioners $(n=16)$; and occupational therapists $(n=38)$. Seeing that some controversy still exists about the rate of return in mail surveys without reminders, the rate of $29 \%$ was acceptable, considering that $20 \%-25 \%$ is usually expected for a mailed survey without reminders (Mangione, 1995:62). Some authors (Alreck \& Settle, 1995:35; Mangione, 1995: 62, 71; Leedy \& Ormrod, 2001:208) reported that the numbers could be as high as $40 \%$, or drop as low as $10 \%$, which indicated that $29 \%$ could be regarded as being sufficient for the purpose of this study and it was therefore decided not to send out reminders.

\section{Sources of information}

Questions were asked in order to determine current sources of information and to identify needs for the future. Figure 1 shows clearly where and how the group as a whole obtained their information, whereas Figure 2 shows in more depth where the three subgroups preferred to obtain their information.

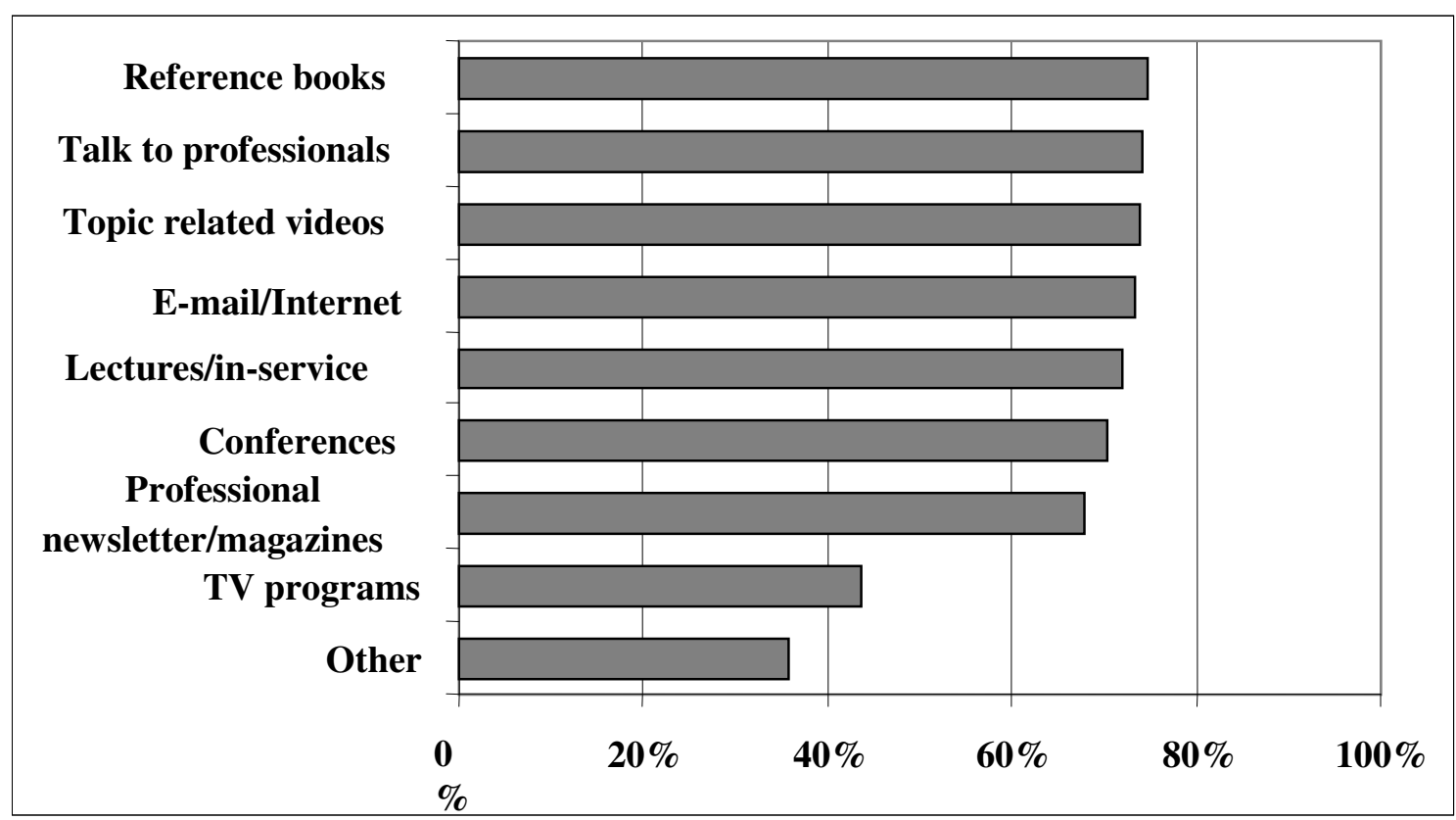

Figure 1: Sources of Information $(n=85)$ 
According to Figure 1, almost all health workers (94\%) seemed to find talking to professionals or colleagues beneficial and $80 \%$ relied heavily on reference books as sources of information. This might be because reference books were acquired during their studies and were therefore readily available. Almost all (95\%) occupational therapists and $71 \%$ of the speechlanguage therapists and audiologists used reference books in contrast to only a third (33\%) of the medical practitioners (see Figure 2). This specific group of health workers tended to rely heavily $(80 \%)$ on professional magazines and newsletters to keep them informed.

Most (84\%) of these professionals seemed to regularly attend conferences, lectures and in-service training sessions. This tendency might be related to the continued professional development required from health workers to maintain their professional registration status. Medical practitioners seemed to lack time or could not afford to be absent from their consulting rooms as only half (52\%) of them indicated conferences and only $30 \%$ indicated that they attended lectures and/or inservice training. The Internet and e-mail seemed to be major sources of information (65\%), but nevertheless used less often than reference books (80\%). Almost all therapists (96\%) used the Internet in comparison to only $40 \%$ of the medical practitioners. As a group (Figure1), only a third of all health workers indicated television and videos as options but when Figure 2 is scrutinised, it becomes clear that therapists watched topicrelated video's and even relied on related television programmes to some extent. Therapists, especially occupational therapists (96\%), often used the Internet and e-mail whereas only $40 \%$ of medical practitioners preferred this source of information. The majority $(83 \%)$ of medical practitioners preferred to use "other" unknown sources of information indicating personal correspondence. There were also a number of medical practitioners who indicated in the "other" section that they used journals. This could be attributed to the fact that the option of journals was not specified in the questionnaire although it was implicated in the option of "newsletters/magazines" and was therefore misleading.

\section{Access to computers}

The following two questions in the questionnaire determined access to computers both within their work environment, as well as outside their work environment. The data displayed in Figure 3 indicates that $83.7 \%$ of the health workers had access to

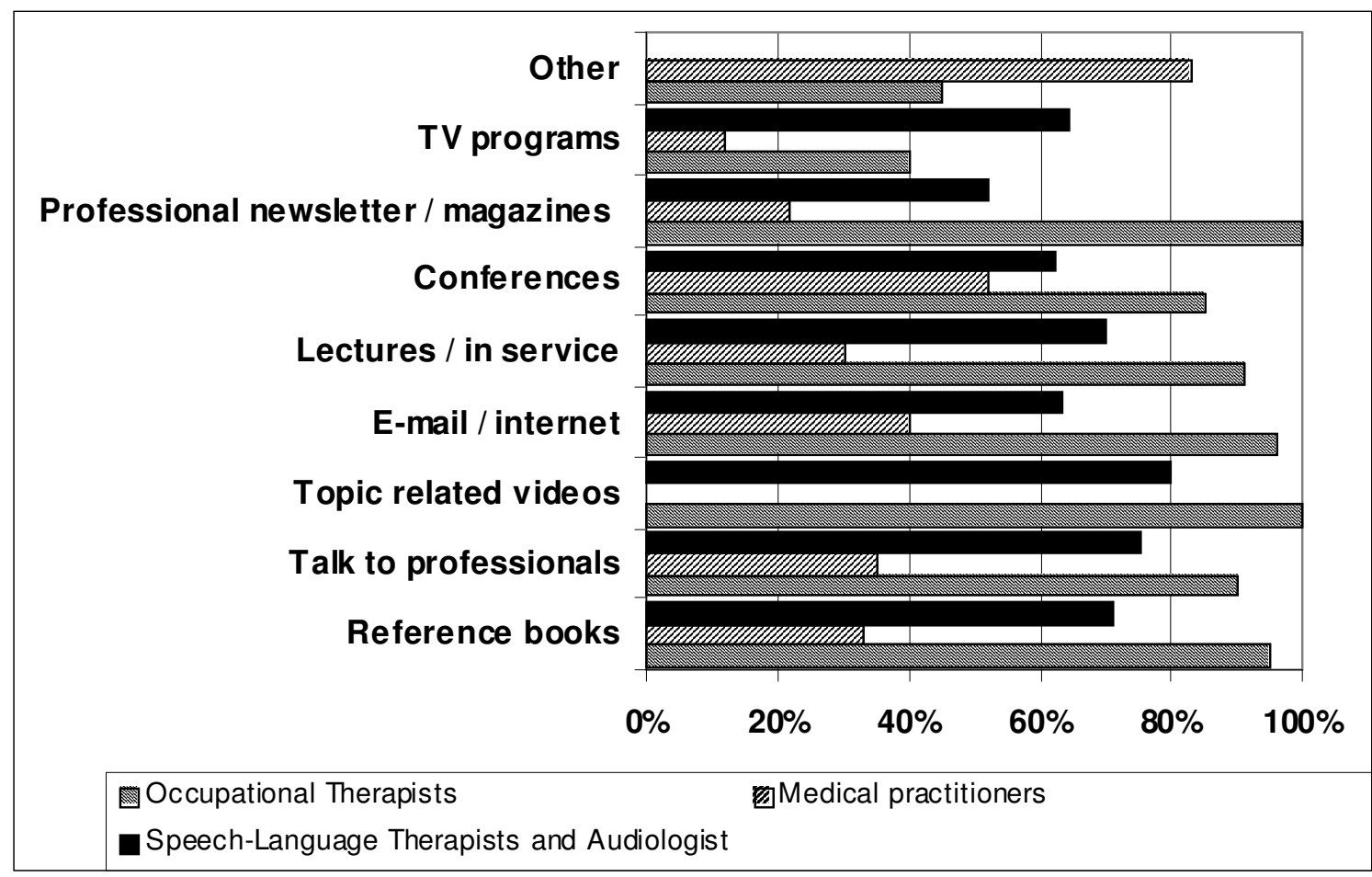

Figure 2: Sources of information among the three sub-groups: STA ( $n=31)$, OT's $(n=38) \& M P(n=16)$ 
computers outside their work environment and almost all $(90.7 \%)$ had access to computers within their work environment.

Most consulting rooms and professional environments had computers for administrative purposes and most professionals had computers in their work environment for personal use.

\section{Use of the Internet and e-mail}

Two questions concerning the use of the Internet and e-mail determined the potential for a proposed website. Figure 4 displays the frequency of Internet and e-mail use and shows that very few (13\% and $11 \%$ respectively) of this group did not use it at all, which correlates with results shown in Figure 3 where very few of the participants indicated that they did not have access to computers inside or outside their work environment. More than half (56\%) of the participants used e-mail often, but this did not imply that they used the Internet equally as much. Almost $80 \%$ used both the Internet as well as e-mail when the "sometimes" and "often" categories were combined. It seemed as if the use of one implied the use of the other, probably because the access to e-mail implies access to the internet.

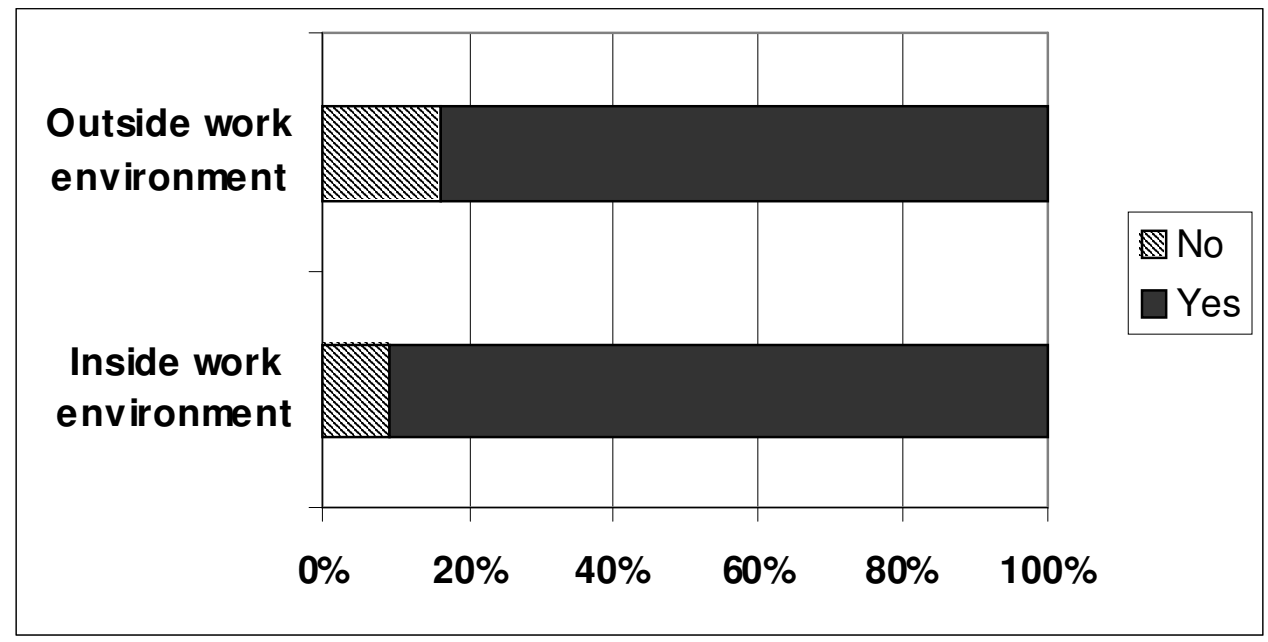

Figure 3: Access to computers inside the work environment $(n=85)$

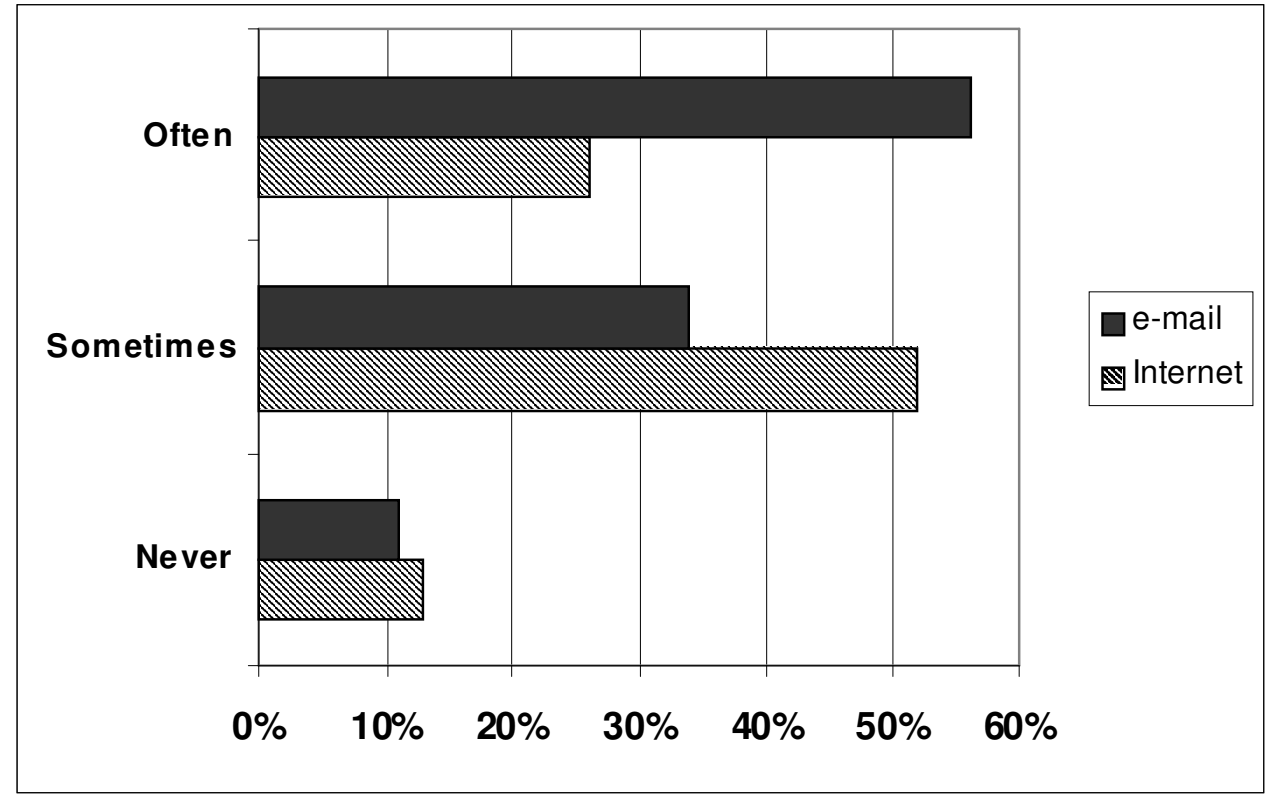

Figure 4: Frequency of Internet and e-mail use $(n=85)$ 


\section{Need of a proposed website with specific information about children}

The participants were asked about their potential utilisation of a proposed website with information about children who experience barriers to the development of listening, language and learning skills. They were asked about the manner they intended using it (for self, for referrals only, or for both), and also the expected frequency of such use. Figure 5 shows that almost all (98\%) of the health workers indicated their intentions of using a proposed website in future which implied a great need for such a proposed website.

\section{Newsletter}

The issue regarding the newsletter was presented and was two-fold:
- How participants wished to receive it (via regular mail, electronic mail or not at all).

- Frequency of newsletter delivery (quarterly, twice a year, annually or not at all).

From Figure 6 it can be derived that as many as $71 \%$ of the health workers preferred the newsletter via electronic mail whereas half of them would also have liked to receive it via regular mail. Apparently $21 \%$ would have liked to receive it via both electronic mail and regular mail. Results portrayed in Figure 6 support those displayed in Figure 8 indicating that $81 \%$ of health workers wished to receive the newsletter as a website function. All respondents were required to indicate how frequently they wished to receive their newsletter and according to Figure 7, the majority $(78 \%)$ preferred a quarterly issue.

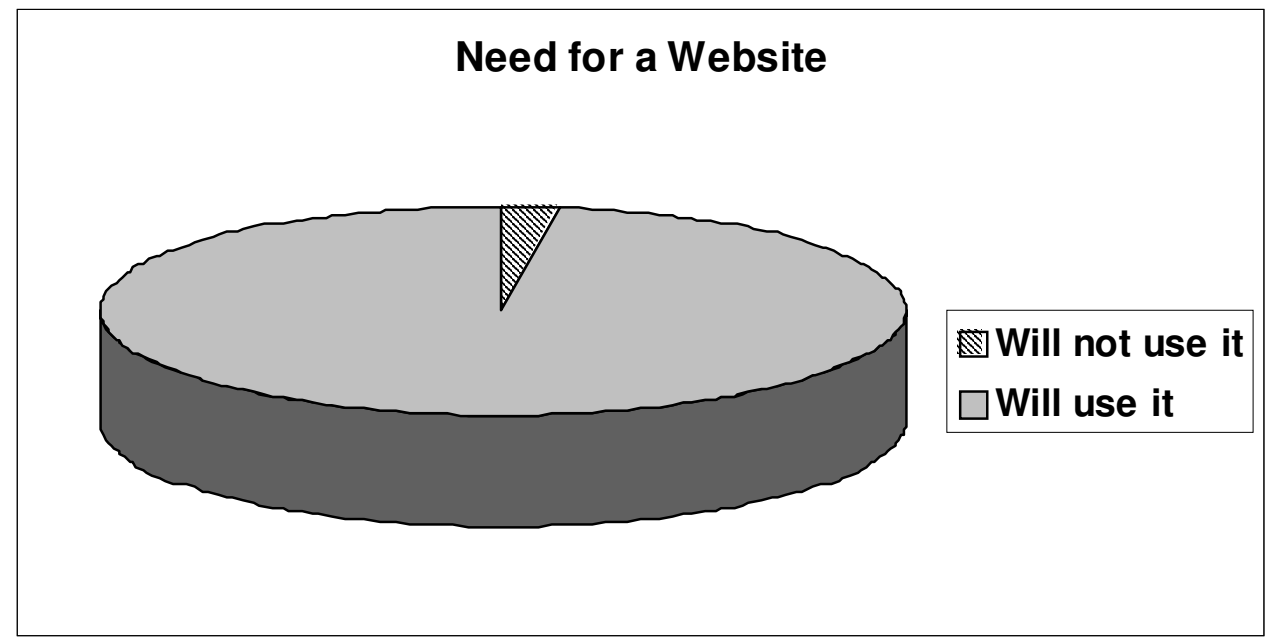

Figure 5: Need for a proposed website ( $n-85)$

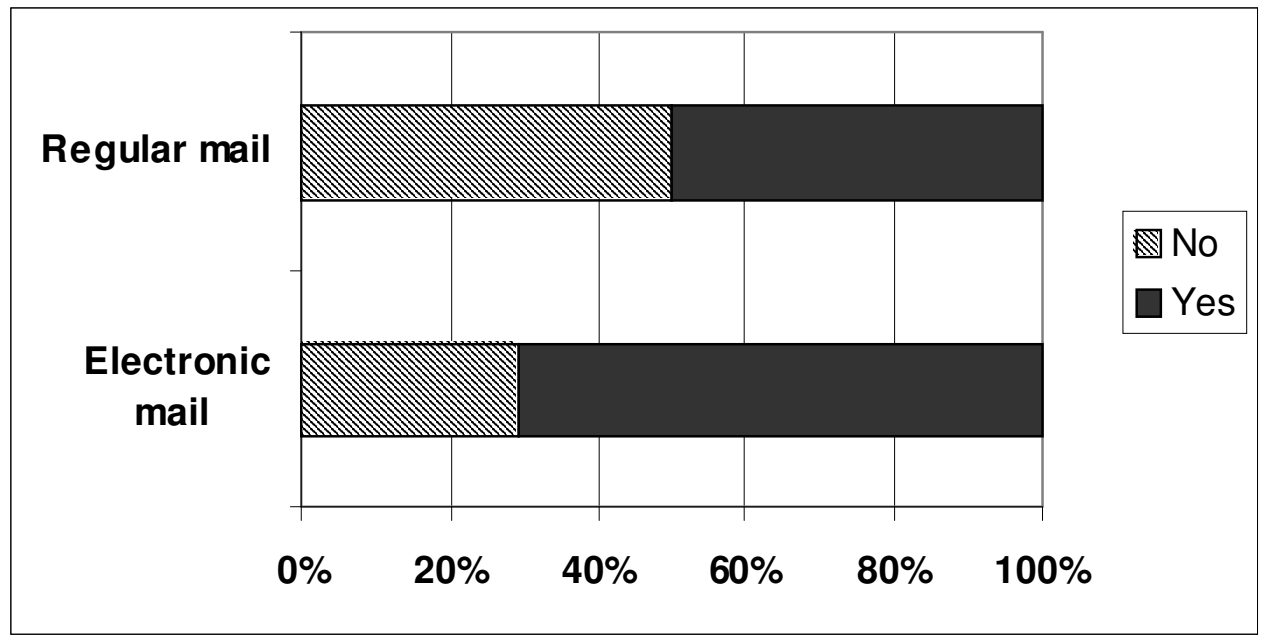

Figure 6: Preference of newsletter delivery $(n=85)$ 


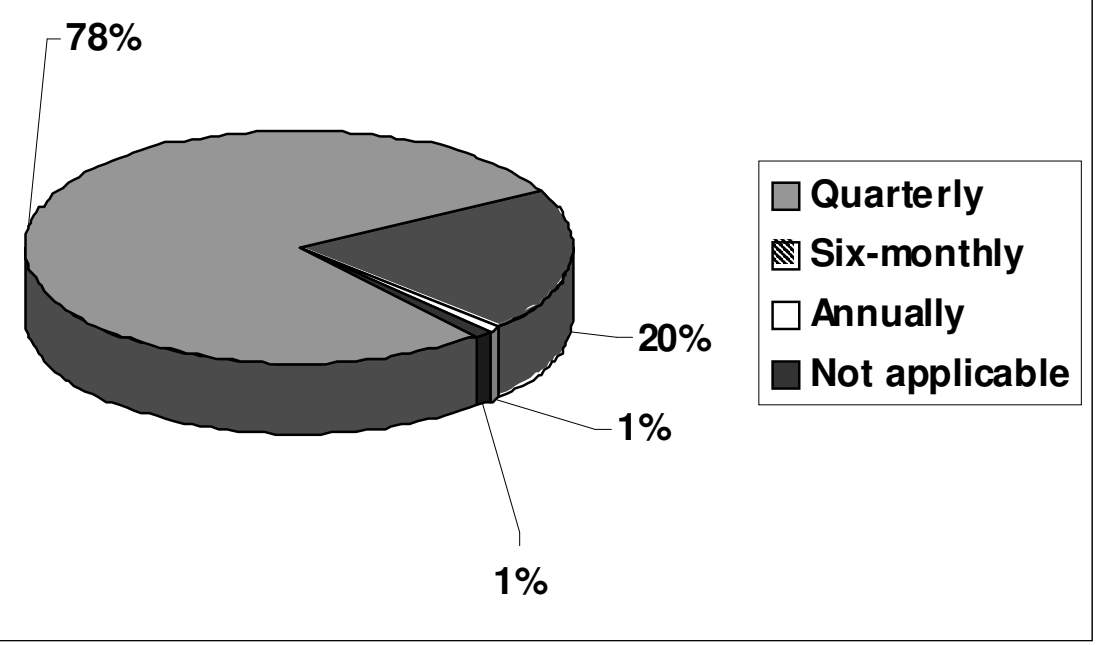

Figure 7: Frequency of newsletter delivery $(n=85)$

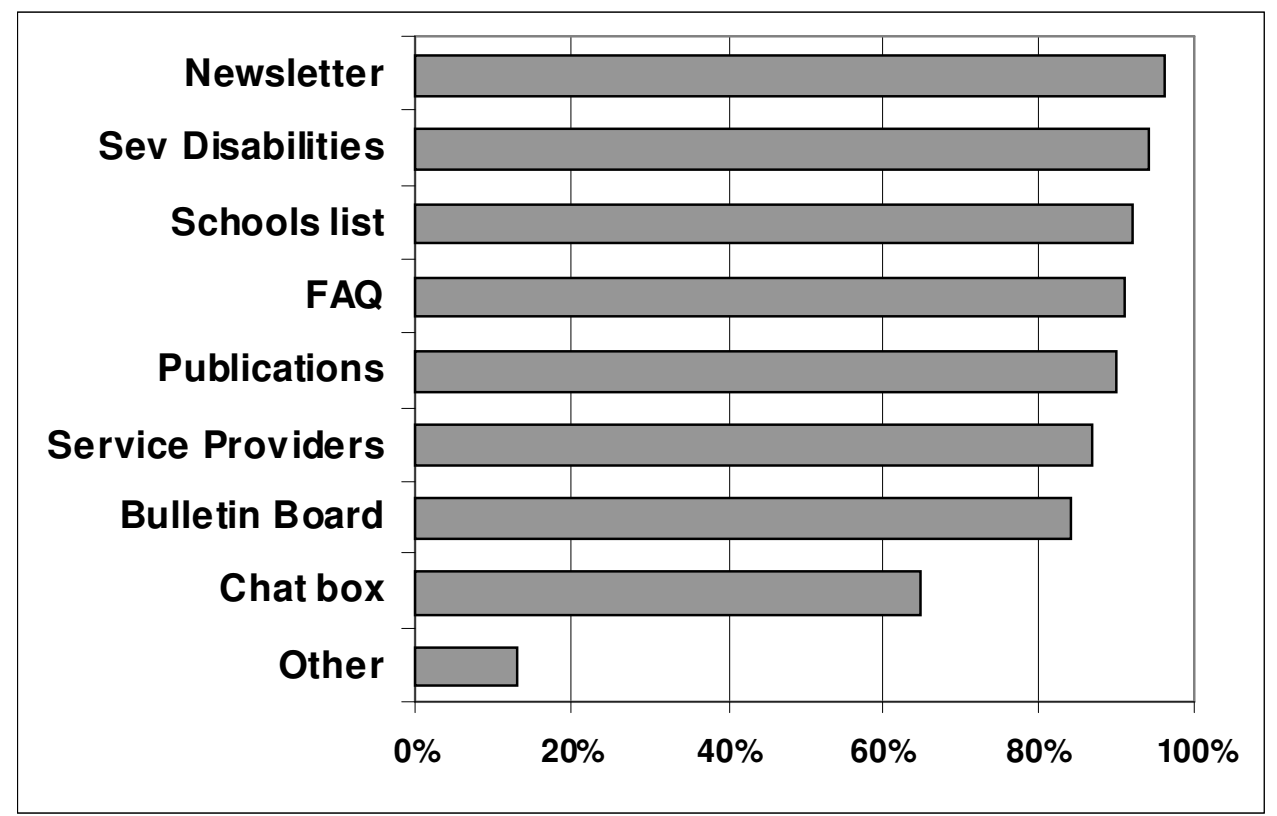

Figure 8: Preferences for functions on the website $(n=85)$

\section{Preferred functions}

Respondents were asked to select their preferences from a list of functions for the website. Figure 8 summarises the options specified by all three groups. The results in Figure 8 indicated that health workers needed almost all listed functions. Only half (50\%) of the respondents requested an interactive "chat room". This function was not a high priority, probably due to the fact that people in general were unfamiliar with the term. There were almost no additional requests for functions on the proposed website and it seemed as if this suggested list would meet their information needs. One other option to be examined related to the need for links to other websites in South Africa as well as internationally. The need for publications with information specifically directed at the target group of children was also indicated.

\section{Need to be listed in the website}

All respondents were asked whether they wished to be listed in the data base of the website. Figure 9 shows that the majority of respondents wished to be listed in the database. It is possible that they regarded this option as a way of advertising. 


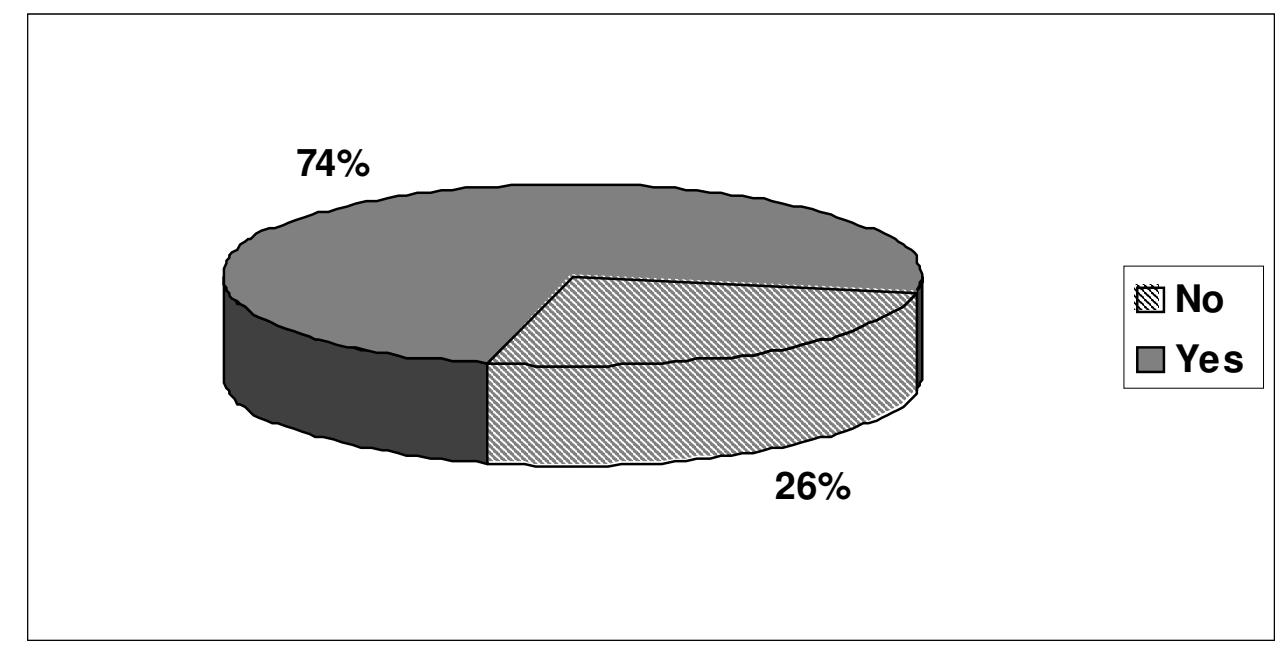

Figure 9: Need of health workers to be listed on the website $(n=85)$

Of those who did not want to be listed, $20 \%$ indicated their wish to adopt a "wait-and-see" approach until a later stage.

\section{CONCLUSIONS}

The majority of health workers obtained the bulk of their required information from reference books and journals. Although the use of the Internet was not indicated as their major source of information, almost all participants were active users of computers and the Internet, being in a position to obtain information electronically. The nature of these respondents' occupations places them in positions where they have to provide information to parents/caregivers of children with special educational needs. They are also the professionals who are in the position to identify these children's potential risk factors and they are responsible for making referrals and recommendations with regard to interventions. It is therefore very important to supply these key role players with relevant electronic information that could aid in the process of early intervention, which in turn will benefit not only children with specific special needs, but also society as a whole. Service providers will be better informed and equipped to provide improved services to their clients. Informed parents could deal with the demands placed on them and also be empowered by acquiring knowledge and accessing the latest information on the Internet.

A definite need existed for a proposed website with appropriate information. Specific information needs included a database with lists of special schools and service providers as a high priority. The majority of respondents also wished to be listed on such a database. A complete database of service providers and educational facilities would enhance the process of referrals. A need for a quarterly newsletter with relevant information was also identified. It could be concluded that health workers wanted to be efficient and required information to this end. Since it was apparent that a website with specific information should be developed to support health professionals in their work, a project was subsequently launched to develop such a website according to the determined needs and preferences

\section{THE KOMMUNIKA WEBSITE}

The results of the survey provided sufficient information to develop the KOMMUNIKA website with relevant information for parents, speech-language therapists and audiologists as well as medical practitioners and occupational therapists with an interest in children who experience barriers to the development of listening, language and learning. Kommunika is part of the Centre for Early Intervention at the Department of Communication Pathology, University of Pretoria. During the first four months of the website's operation, 200 people visited the website. Kommunika maintains and updates the website on a monthly basis. The website (www.up.ac.za/academic/kommunika) provides contact details such as telephone numbers and e-mail addresses for contributions or inquiries. All functions listed in the discussion of the research 
results have been implemented, with the exception of the chat room, which requires a higher frequency of visits to justify full time staffing. This website will be evaluated, and if necessary upgraded at regular intervals for continued relevance, efficiency and appropriateness.

\section{REFERENCES}

Aldrich, DF 1999: Mastering the digital market place. New York: John Wiley.

Alderson, P \& Goodey, C 1998: The doctor, ethics and special education. Journal of Medical Ethics, 24(1):48.

Alreck, PL \& Settle, RB 1995: The survey research handbook. New York: Irwin Professional.

Blackburn, N 2001: Building bridges. Towards integrated library and information services for mental health and social care. Health Information and Libraries Journal, 18(4):203-212.

Davidson, EJ; Silva, TJ; Sofis, LA; Ganz, M \& Palfrey, JS 2002: The doctor's dilemma. Challenges for the primary care physician caring for the child with special health care needs. Ambulatory Pediatrics, 2(3):218-223.

Driscoll, A \& Nagel, N 2002: Early childhood education: Birth to 8. Boston: Allyn \& Bacon.

Fink, A 1995(a): How to ask survey questions. The survey kit. London: Sage.

Fink, A 1995(b): How to sample in surveys. The survey kit. London: Sage.

Fouche, S\& Naudé, E 1999: Die kommunikasiepatoloog en individuele diensplan-ontwikkeling in Suid Afrika. Clinica: Applications in Clinical Practice of Communication Pathology, Monograph 4:11-12. Hendrickson, S; Baldwin, JH; \& Allred KW 2000: Factors perceived by mothers as preventing families from obtaining early intervention services for their children with special needs. Children's Health Care, 29(1):1.

Kommunika website: http://www.up.ac.za/academic/kommunika/ Leedy, PD \& Ormrod, S 1989: Practical research, planning and design. New York: MacMillan.

Magnusson, L; Hanson, E; Brito, L; Berthold, H; Chambers, M \& Daly, T 2002: Supporting family carers through the use of information and communication technology. The EU project ACTION. International Journal of Nursing Studies, 39(4):369-381.

Maisel, R \& Persell, CH 1996: How sampling works. Thousand Oaks: Pine Forge.

Mangione, RW 1995: Mail surveys. Improving the quality. Thousand Oaks: Sage.

Mitchell, W \& Sloper, P 2002: Information that informs rather than alienates families with disabled children. Developing a model of good practice. Health \& Social Care in the Community, 10(2):74 -
81.

Naudé, E 2003: The pre-school years: Looking from the inside to the outside. Kommunika Seminar. www.up.ac.za/academic/ kommunika.

Naude, C 1997: Fokus op tegnologie. Finansies en Tegniek, 26 September:43-47.

Pain, H 1999: Coping with a child with disabilities from the parents' perspective. The function of information. Child: Care, Health \& Development, 25(4):299-312.

Pickering, M; McAllister, L; Hagler, P; Whitehill, TL; Penn, C; Robertson, SJ \& McCready, V 1998: External factors influencing the profession in six societies. American Journal of Speech-Language Pathology, 7(4):5-17.

Pickett Hauber, R; Vesmarovich, S \& Dufour, L 2002: The use of computers and the Internet as sources of health information for people with disabilities. Rehabilitation Nursing, 27(4):142-143.

Science Panel on Interactive Communication and Health 1999: Wired for health and well-being. The emergence of interactive health communication. Washington, DC: US Department of Health and Human Services, Office of Public Health and Science.

Smith, VK \& Prelock, A 2002: A case management model for schoolage children with multiple needs. Language, Speech, \& Learning in Schools, 33(2):24-126.

Starke, M \& Moller, A 2002: Parents' needs for knowledge concerning the medical diagnosis of their children. Journal of Child Health Care, 6(4):245-257.

Taanila, A; Syrjala, L; Kokkonen, J \& Jarvelin, MR 2002: Coping of parents with physically and/or intellectually disabled children. Child: Care, Health \& Development, 28(1):73-86.

Tapscott, D 1999: Introduction. Creating value in the network economy. Boston: Harvard Business School. 